\title{
BOLE PROFILE OF EUCALYPTUS UNDER TWO CONDUCTION REGIMES IN THE SOUTHWEST REGION OF THE BRAZILIAN STATE BAHIA ${ }^{1}$
}

Gileno Brito de Azevedo ${ }^{2 *}$, Glauce Taís de Oliveira Sousa Azevedo ${ }^{3}$, Renato Vinícius de Oliveira Castro ${ }^{4}$, Patrícia Anjos Bittencourt Barreto-Garcia ${ }^{5}$ and Alba Valéria Rezende ${ }^{6}$

\footnotetext{
${ }^{1}$ Received on 04.04.2015 accepted for publication on 28.11.2016.

${ }^{2}$ Universidade Federal de Mato Grosso do Sul, Campus de Chapadão do Sul, Chapadão do Sul, MS - Brasil. E-mail: <gileno.azevedo@ufms.br>.

${ }^{3}$ Universidade de Brasília, Programa de Pós-Graduação em Ciências Florestais, Brasília, DF - Brasil. E-mail: <gtosousa@gmail.com>. ${ }^{4}$ Universidade Federal de São João del Rei, Departamento de Ciências Agrárias, Sete Lagoas, MG - Brasil. E-mail: <castrorvo@ymail.com>. ${ }^{5}$ Universidade Estadual do Sudoeste da Bahia, Departamento de Engenharia Agrícola e Solos, Vitória da Conquista, BA - Brasil. E-mail:<patriciabarreto@uesb.edu.br>.

${ }^{6}$ Universidade de Brasília, Faculdade de Tecnologia, Departamento de Engenharia Florestal, Brasília, DF - Brasil. E-mail: <albavr@unb.br>.

*Corresponding author.
}

\begin{abstract}
The study of the bole profile is an important tool in the forest production management, which is influenced by several factors, such as the stand conduction regime. This work aimed to evaluate two stand conduction regimes regarding the Eucalyptus urophylla bole in the southwest region of the Brazilian state, Bahia. The data used was retrieved from stands conducted under high forest and coppice regimes. The tapering models proposed by Kozak, Demaerschalk, Ormerod, Garcia and Garay were adjusted, being selected the ones that presented better performances regarding adjustment statistics and graphic analysis of residue for each conduction regime. The models selected were validated by the chi-squared test $(\alpha=0,05)$. Considering the models selected, it was possible to estimate the value of the diameter along the bole of the average-tree, allowing to evaluate the bole profile for each stand conduction regime. The identity test of the models showed that the stand conduction regime affects the shape of the trees' bole, making a necessity to adjust a specific equation for each situation. The bole tends to present a cylindrical form in a stand conducted in a coppice regime and conical one in a high forest regime.
\end{abstract}

Keywords: Tapering functions; Bole shape; Coppice.

\section{PERFIL DO FUSTE DE EUCALIPTO SOB DOIS REGIMES DE CONDUÇÃO NO SUDOESTE DA BAHIA}

\begin{abstract}
RESUMO - O conhecimento do perfil do fuste é em uma ferramenta importante no manejo da produção florestal, sendo o mesmo influenciado por diversos fatores, como o regime de condução do povoamento. O presente trabalho objetivou avaliar a influência de dois regimes de condução do povoamento sobre o perfil do fuste de Eucalyptus urophylla, na região sudoeste da Bahia. Foram utilizados dados de povoamentos conduzidos pelo regime de alto fuste e talhadia. Os modelos de afilamento propostos por Kozak, Demaerschalk, Ormerod, Garcia e Garay foram ajustados, sendo selecionado aquele com melhor desempenho nas estatísticas de ajuste e análise gráfica de resíduos, para cada regime de condução. Os modelos selecionados foram validados utilizando o teste do qui-quadrado $(\alpha=0,05)$. Diante dos modelos selecionados, foram estimados os valores do diâmetro ao longo do fuste da árvore média, permitindo avaliar o perfil do fuste para cada regime de condução do povoamento. O teste de identidade de modelos mostrou que o regime de condução do povoamento influencia a forma do fuste das árvores, sendo necessário o ajuste de uma equação específica para cada situação. Ofuste tende a apresentar forma mais cilindrica em povoamento conduzido sob regime de talhadia e mais cônica no regime de condução por alto fuste.
\end{abstract}

Palavras-chave: Funções de afilamento; Forma do fuste; Talhadia.

Revista Árvore. 2017;41(2):e410211

http://dx.doi.org/10.1590/1806-90882017000200011 


\section{INTRODUCTION}

Knowing the bole profile of some commercial forestry species, such as the eucalyptus, consists in an important tool for the forest production management. Among the ways of understanding the bole profile, the tapering functions are highlighted, once they express the decreasing of the diameter rate along the bole and allow predicting three basic characteristics of the tree: diameter at any height of the tree, total height or where it stands in a limit diameter and volume between any points of the bole (Prodan et al., 1997; Silva et al., 2006; Horle et al., 2010; Leite et al., 2011; Campos and Leite, 2013; Môra et al., 2014; Miguel et al., 2015; Özçelik and Crecente-Campo, 2016), in function of the bole's length and minimal diameter (Chichorro et al., 2003).

Several factors can affect the bole profile of a tree, among them: species, genetic material, age of the tree, stand spacing, cut regime and thinning, stand conduction regime, site and length and width of the crown (Nogueira et al., 2008; Queiroz et al., 2008; Campos and Leite, 2013; Batista et al., 2014; Andrade et al., 2016; RodríguezToro et al., 2016; Souza et al., 2016; Kohler et al., 2016; Vendruscolo et al., 2016). These factors have encouraged the researchers to develop and apply the bole profile modeling under different conditions.

The eucalyptus stands, generally, are designed to charcoal production, in order to provide material to the steel industry, as well for cellulose and paper, being managed under at least one coppice (Cacau et al., 2008), highlighting a growth in areas conducted under this system in the last few years (Abraf, 2013). Therefore, stands conducted by coppice started to receive more attention from the foresters and researchers, constituting in a good option for forest management due its economic viability (Gonçalves et al., 2014).

It is common to observe that the sprouts conduction generates an inferior volume of wood per bole when compared to the stand reform (Azevedo et al., 2011; Ferraz Filho et al., 2014). However, the literature lacks information regarding the conduction regime effects (high forest or coppice) on the bole profile. Knowing the bole profile of arborous specimens under these conditions can constitute in a relevant tool to define different uses for the trunk, increasing their use potential and adding commercial value to the final product. Considering that, this work aimed to evaluate the influence of the stand conduction regime (high forest and coppice) on the bole of Eucalyptus urophylla, in the southwest region of the Brazilian state Bahia.

\section{MATERIALAND METHODS}

This work was performed in Eucalyptus urophylla stands, located at the Bela Vista Farm, at the Vitória da Conquista town, in the Brazilian state Bahia. The region's relief is plane and slightly wavy, located in an even height at $880 \mathrm{~m}$ from the soil. The climate in the region is subtropical highland climate $(\mathrm{Cwb})$, according to the Köppen classification, with an average temperature of $21{ }^{\circ} \mathrm{C}$ and annual rainfall varying from 700 to $1,100 \mathrm{~mm}$, distributed between November and March, with a dry season of four or five months.

The data used was obtained in two stands planted in a spacing of $3 \times 2 \mathrm{~m}$ at the age of 5 , conducted under two conduction regimes, high forest and coppice (first coppice). The coppice was conducted from the strains sprouting, measuring $10 \mathrm{~cm}$ and sprout thinning at the $12^{\text {th }}$ month after the cut and keeping two sprouts per stump. The choice for the age of 5 is due to the majority of stands of the region being designed for the wood production for energy, with harvest cycles at the age of 4 and 5 .

In the stand under the high forest regime was randomly selected and downed 35 trees, distributed in four diameter classes, considering a DBH (diameter at breast height) variation between 8.7 and $16.9 \mathrm{~cm}$ and a height varying between 10.2 to $16.5 \mathrm{~m}$. As for the stand in coppice regime, 59 boles were downed, originating 30 stumps, randomly selected, with a DBH varying between 6.2 and $15.3 \mathrm{~cm}$ and a height varying between 10.6 and $16.8 \mathrm{~m}$ (Azevedo et al., 2011). In the last stand, for calculations and equations adjustment effects, each bole resulted from the sprouts' conduction was considered an individual. On both stands, the trees were scaled by the Smalian method, measuring the diameter with bark along the bole at $0.1,0.3,0.7,1.3$ and $2 \mathrm{~m}$ from the soil, from that point, the sections were measured from 2 in $2 \mathrm{~m}$, until the reaching a minimum diameter of $4 \mathrm{~cm}$.

The scaling data of each conduction regime was separated for the model's adjustment and validation. In the adjustment, the data used was obtained from 25 trees randomly selected, for the area conducted 
under high forest, as for the area conducted under coppice, the data was provided by 49 boles. Considering the tapering models of Kozak, Demaerschalk, Ormerod, Garcia and Garay, whose functional relations and expressions to estimate the diameter (d) at any height of the bole, as described next:

a) Kozak et al. (1969)

$$
\begin{aligned}
& \left(\frac{d}{D B H}\right)^{2}=\beta_{0}+\beta_{1} \cdot\left(\frac{h}{H t}\right)+\beta_{2} \cdot\left(\frac{h}{H t}\right)^{2}+\varepsilon \\
& \hat{d}=D B H \cdot \sqrt{\hat{\beta}_{0}+\hat{\beta}_{1} \cdot\left(\frac{h}{H t}\right)+\hat{\beta}_{2} \cdot\left(\frac{h}{H t}\right)^{2}}
\end{aligned}
$$

b) Demaerschalk (1972)

$$
\left(\frac{d}{D B H}\right)^{2}=10^{2 \beta_{0}} D A P^{\left(2 \beta_{1}-2\right)} H t^{2 \beta_{2}}(H t-h)^{2 \beta_{3}}+\varepsilon
$$$$
\hat{d}=10^{\hat{\beta}_{0}} \cdot D B H^{\hat{\beta}_{1}} \cdot H t^{2 \hat{\beta}_{2}} \cdot(H t-h)^{2 \hat{\beta}_{3}}
$$

c) Ormerod (1973)

$$
\begin{aligned}
& \left(\frac{d}{D B H}\right)^{2}=\left(\frac{H t-h}{H t-1,3}\right)^{2 . \beta_{1}}+\varepsilon \\
& \hat{d}=D B H \cdot\left(\frac{H t-h}{H t-1,3}\right)^{\hat{\beta}_{1}}
\end{aligned}
$$

d) Garcia et al. (1993)

$$
\begin{aligned}
& \left(\frac{d}{D B H}\right)^{2}=\beta_{0}+\beta_{1} \cdot \sqrt{\frac{h}{H t}}+\beta_{2} \cdot\left(\frac{h}{H t}\right)+\varepsilon \\
& \hat{d}=D B H \cdot \sqrt{\hat{\beta}_{0}+\hat{\beta}_{1} \cdot\left(\frac{h}{H t}\right)^{1 / 2}+\hat{\beta}_{2} \cdot\left(\frac{h}{H t}\right)}
\end{aligned}
$$

e) Garay (1979)

$$
\begin{aligned}
& \left(\frac{d}{D B H}\right)=\beta_{0}\left(1+\beta_{1} \cdot \operatorname{Ln}\left(1-\beta_{2} \cdot h^{\beta_{3}} \cdot H t^{-\beta_{3}}\right)\right)+\varepsilon \\
& \hat{d}=D B H \cdot \hat{\beta}_{0}\left(1+\hat{\beta}_{1} \cdot \operatorname{Ln}\left(1-\hat{\beta}_{2} \cdot h^{\hat{\beta}_{3}} \cdot H t^{-\hat{\beta}_{3}}\right)\right)
\end{aligned}
$$

In which: $d=$ diameter at height $\mathrm{h}$, in $\mathrm{cm} ; D B H=$ diameter at $1.30 \mathrm{~m}$, in $\mathrm{cm} ; h=$ height at any part of the bole, in $\mathrm{m} ; H t=$ total height, in $\mathrm{m} ; \beta i=$ parameters to be estimated by the regression; and $\varepsilon=$ random error.
The linear models were adjusted by the ordinary minimum square method and the non-linear models were adjusted by the Statistica 7.0 software (Statsoft, 2004), using the Levenberg-Marquardt algorithm with 1,000 interactions. The best model for each conduction regime was selected based on the correlation coefficient between values observed and estimated (r), adjusted determination coefficient $\left(\mathrm{R}^{2}{ }_{\mathrm{aj}}\right)$, standard residual error in percentage $\left(\mathrm{S}_{\mathrm{yx}} \%\right)$ and graphic distribution of the residue (Draper and Smith, 1981), obtained for the diameter variable (d) at any height of the bole.

To evaluate the adherence of the model selected in the diameter estimated for each conduction regime, the data obtained from 10 trees (high forest) and 10 boles (coppice), that were not used in the models' adjustment, was validated by applying the chi-squared method $\left(\chi^{2}\right)(\alpha=0,05)$ (Silveira, 2009).

After selecting the best tapering model for each conduction regime, the values for diameter along bole for the average tree were estimated, considering all the trees measured, allowing to present graphically the profile of the bole for each conduction regime at the stand. Therefore, it was considered as the average-tree the one with mean diameter $(\mathrm{q})$ and arithmetic average of the height $(\mathrm{Ht})$ of the sampletrees, according to Nogueira et al. (2008).

The model identity test (Regazzi, 2003) was used to verify if the equations adjusted of both stands were statistically equal, in other words, if the only equations could be used to estimate the bole profile for both stands (Campos and Leite, 2013).

\section{RESULTS}

From the analysis of the adjustment statistics (Table 1) and graphic distribution of the residue of the five tapering models evaluated (Figure 1), it was verified that the Garay model presented the best precision measurements, for both, the stand conducted under the high forest regime and coppice. This model presented the lowest standard residual error (under 7\%) and better graphic distribution of the residue, with a homogeneous distribution and lower error amplitude. The greater dispersion of the residue, considering all models adjusted, occurred at the superior part of the bole (top), where the diameters are lower (Figure 1). 

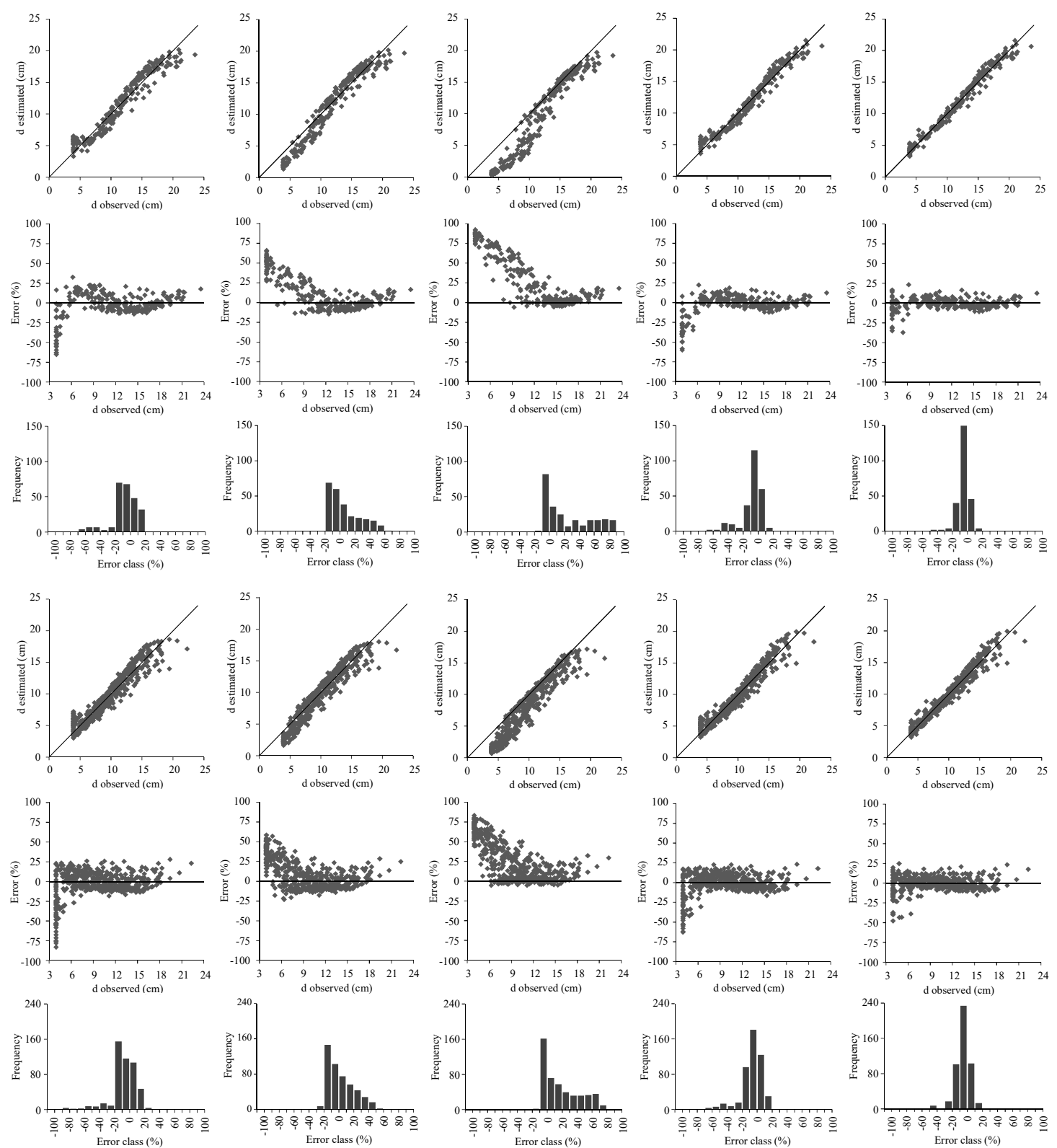

Figure 1 - Graphic distribution of the residue for tapering models adjusted under different conduction regimes of Eucalyptus urophylla in the southwest region of the Brazilian state Bahia.

Figura 1 - Distribuição gráfica dos resíduos para os modelos de taper ajustados em diferentes regimes de condução de Eucalyptus urophylla no sudoeste da Bahia.

As for validating the equations obtained by adjusting the Garay model, on both stands studied, it was verified that the diameters observed along the bole were statistically equal to the diameters estimated $(\mathrm{p}<0.05)$ (high forest: $\chi_{\text {tabled }}^{2}=120.99 ; \chi_{\text {calculated }}^{2}=5.66$; coppice: $\left.\chi_{\text {tabled }}^{2}=124.34 ; \chi_{\text {calculated }}^{2}=5.79\right)$.
On the graphic that represents the profile of the bole for the average-tree on both stands studied (Figure 2), it is observed that there are differences between the shapes of the boles on both conduction regimes. It is possible to notice that the bole in the coppice regime is less conical than in the high forest regime. 
Table 1 - Parameters estimates for the model and adjustment statistics for the diameter variable (d) in all conduction regimes of Eucalyptus urophylla in the southwest region of the Brazilian state Bahia.

Tabela 1 - Estimativa dos parâmetros dos modelos e estatísticas de ajuste para a variável diâmetro (d) para diferentes regimes de condução de Eucalyptus urophylla no sudoeste da Bahia.

\begin{tabular}{|c|c|c|c|c|c|c|c|c|}
\hline \multirow[t]{2}{*}{ Conduction } & \multirow[t]{2}{*}{ Model } & \multicolumn{4}{|c|}{ Regression coefficients } & \multicolumn{3}{|c|}{ Adjustment statistics } \\
\hline & & $\beta_{0}$ & $\beta_{1}$ & $\beta_{2}$ & $\beta_{3}$ & $\mathrm{r}$ & $\mathrm{R}^{2}{ }_{\mathrm{aj}}$ & $\mathrm{S}_{\mathrm{yx}} \%$ \\
\hline \multirow[t]{5}{*}{ High Forest } & Kozak & 1.5131 & -3.5535 & 2.3056 & - & 0.9634 & 0.9275 & 14.82 \\
\hline & Demaerschalk & 0.3401 & 0.9733 & -1.3873 & 1.1937 & 0.9722 & - & 20.85 \\
\hline & Ormerod & - & 1.8599 & - & - & 0.9685 & - & 71.54 \\
\hline & Garcia & 1.9606 & -3.2748 & 1.4068 & - & 0.9810 & 0.9621 & 7.74 \\
\hline & Garay & 2.0007 & 0.2150 & 0.9882 & 0.0425 & 0.9892 & - & 4.43 \\
\hline \multirow[t]{5}{*}{ Coppice } & Kozak & 1.5185 & -3.4636 & 2.2685 & - & 0.9542 & 0.9102 & 15.07 \\
\hline & Demaerschalk & 0.1659 & 0.9070 & -1.0312 & 1.0483 & 0.9607 & - & 18.09 \\
\hline & Ormerod & - & 1.4272 & - & - & 0.9565 & - & 48.60 \\
\hline & Garcia & 1.9676 & -3.2777 & 1.4419 & - & 0.9704 & 0.9414 & 9.79 \\
\hline & Garay & 2.0050 & 0.2061 & 0.9885 & 0.0387 & 0.9798 & - & 6.76 \\
\hline
\end{tabular}

$\beta i=$ coefficients estimated in the regression; $\mathrm{r}=$ correlation coefficients between values observed and estimated; $\mathrm{R}^{2}{ }_{\text {aj }}=$ adjusted determination coefficient; and $\mathrm{S}_{\mathrm{yx}} \%=$ standard residual error in percentage.
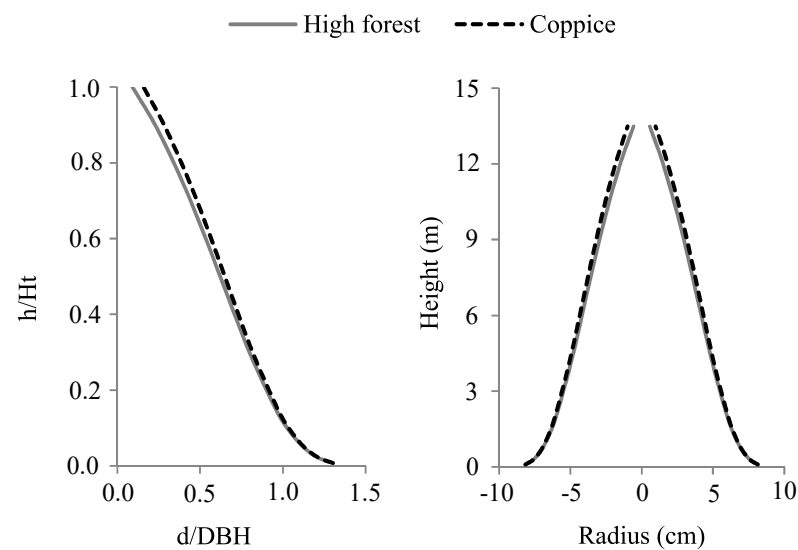

Figure 2 - Profile of the average-tree $(\mathrm{DBH}=12.52$ and $\mathrm{Ht}=13.48$ ) estimated by the Garay model for different conduction of Eucalyptus urophylla in the southwest region of the Brazilian state Bahia.

Figura 2-Perfil da árvore média (DAP $=12,52$ e Ht $=13,48)$ estimado pelo modelo de Garay para diferentes regimes de condução de Eucalyptus urophylla no sudoeste da Bahia.

The identity test of the models proved the existence of significant differences between the equations generated to estimate the diameter along the bole for both conduction regimes studied $\left(\chi_{\text {tabled }}^{2}=9.49 ; \chi_{\text {calculated }}^{2}\right.$ $=24.02 ; \mathrm{p}<0.0001)$.

\section{DISCUSSION}

The results for the adjustment of the tapering functions indicated that the Garay model presents the best performance to estimate the diameter along the bole on both conduction regimes evaluated, thus, it was the selected one. By validating this model, it was proved that both equations selected to estimate the diameter along the bole are statistically valid, which allows estimating precisely the diameter along the bole for each conduction regime. This model also was highlighted due its precision and consistence in estimating the tapering of the bole in Eucalyptus grandis $\mathrm{x}$ Eucalyptus camaldulensis stands under different spatial disposition (Souza et al., 2016), for Eucalyptus grandis X Eucalyptus urophylla stands (Campos et al., 2014), for the Virola surinamensis in the Amazon forest (Leite et al., 2006) and heartwood and bole tapering in a Tectona grandis stand (Leite et al., 2011). According to Leite et al. (2006), this model derived from the Chapman Richards function, its flexible enough to describe the variations in shape of the trees of different species and sizes and consistent with the variables $d, h$ and volume, as demonstrated by Garay (1979).

Regarding the larger residue dispersion on the superior part of the bole (Figure 1), its emphasized that, in general, the tapering models are little flexible to estimate diameters at the base and on the top of the boles (Silva et al., 2011). Normally, the lower diameters present lower absolute values and the estimate for these diameters from the tapering function is susceptible to greater relative errors (Soares et al., 2011). When these errors occur frequently, an alternative to minimize this issue, would be using segmented models (Soares et al., 2011; Menéndez-Miguélez et al., 2014; Tang et al., 2016). 
A tapering function disregarding the stand's conduction regime is inadequate to estimate the diameter at different heights of the bole, since the stand's conduction regime effect (high forest or coppice) over the bole profile (Figure 2) can be confirmed by the identity model test, which indicated the differences between the shape of the bole on both conduction regimes here evaluated, corroborating to the results obtained by Azevedo et al. (2011). These authors, by evaluating the factor $(f)$ and the quotient $(Q)$ of the shape, in the same field, verified slightly superior values for the stand conducted by coppice $(f=0.51$ and $Q=0.67)$, when compared to what was conducted under high forest $(f=0.49$ and $Q=0.64)$, indicating a greater conicity in said conduction system.

The use of tapering functions to describe the profile of the eucalyptus bole compared to different conduction regimes was not found. However, Souza et al. (2016), when evaluated the bole profile of Eucalyptus grandis $\mathrm{x}$ Eucalyptus camaldulensis under different spatial distribution stated that the greater the distance between the plants, more conical is the shape of the bole. Nogueira et al. (2008), by evaluating the influence of different spacing over the shape of the bole of Pinus taeda trees, verified that greater spacing provided the development of conical boles and smaller spacing presented boles with a cylindrical shape. Téo et al. (2013), while evaluating the profile of the bole in Pinus elliottii stands at different ages (10, 18 and 27), verified that the trees at advanced ages present a lower tapering (lower conicity) and, consequently, better shape.

The results found in this work and on the studies cited above, confirm that the shape of the bole profile is associated to the competition between the trees inside a stand. Under lesser competition conditions (such as: greater spacing, lower age), the trees tend to increase in diameter at the base of the bole, to assure greater support to the weight of the trunk and crown. However, when the tress as susceptible to greater competition, the trend to invest on the diameter increment at the superior areas of the bole, which provides a cylindrical shape (Andrade et al., 2007). In this work, the stand conducted under the coppice regime presented a larger number of boles per area unit and, consequently, the competition between the specimens is greater, causing a lesser conical shape on the boles.

\section{CONCLUSIONS}

1. The identity model test revealed that the conduction regime (high forest and coppice) influenced the shape of the trees, being necessary to adjust a specific equation for each situation.

2 . The bole tends to present a cylindrical shape in a stand conducted under coppice regime, and conical under high forest regime.

\section{REFERENCES}

Associação Brasileira de Produtores de Florestas Plantadas - Abraf - Anuário estatístico Abraf 2013: ano base 2012. Brasília, DF: 2013. 148p.

Andrade CM, Finger CAG, Tomas C, Schneider PR. Variação do incremento anual ao longo do fuste de Pinus taeda L. em diferentes idades e densidades populacionais. Ciência Florestal. 2007;17:239-46.

Andrade VCL, Souza AL, Amaro MA, Costa WS, Soares CPB. Perfil do fuste de Anadenanthera peregrina descrito pelo método da altura relativa. Ciência Florestal 2016;26:875-87.

Azevedo GB, Sousa GTO, Barreto PAB, Conceição Junior V. Estimativas volumétricas em povoamentos de eucalipto sob regime de alto fuste e talhadia no sudoeste da Bahia. Pesquisa Florestal Brasileira. 2011;31(68):309-18.

Batista JLF, Couto HTZ, Silva Filho DF. Quantificação de recursos florestais: árvores, arvoredos e florestas. São Paulo: Oficina de Textos; 2014. 384p.

Cacau FV, Reis GG, Reis MGF, Leite HG, Alves FF, Souza FC. Decepa de plantas jovens de eucalipto e manejo de brotações, em um sistema agroflorestal. Pesquisa de Agropecuária Brasileira. 2008;43(11):1457-65.

Campos BPF, Binoti DHB, Lopes da Silva M, Leite HG, Binoti MLMS. Efeito do modelo de afilamento utilizado sobre a conversão de fustes de árvores em multiprodutos. Scientia Forestalis. 2014;42(104):51320:

Campos JCC, Leite HG. Mensuração florestal: perguntas e respostas. Viçosa, MG: Universidade Federal de Viçosa; 2013. 605p.

Chichorro JF, Resende JLP, Leite HG. Equações de volume e de taper para quantificar multiprodutos 
da madeira em Floresta Atlântica. Revista Árvore. 2003;27(6):799-809.

Demaerschalk JP. Converting volume equations to compatible taper equations. Forest Science. 1972;18(3):241-5.

Draper NR, Smith H. Applied regression analysis. $2^{\text {nd }}$. ed. New York: John Wiley; 1981. 709p.

Ferraz Filho AC, Scolforo JRS, Mola-Yudego B. The coppice-with-standards silvicultural system as applied to Eucalyptus plantations - a review. Journal of Forestry Research. 2014;25(2):237-48.

Garay L. Tropical forest utilization system. VIII. A taper model for entire stem profile including buttressing. Seattle: Institute Forest Production University Wash; 1979. 64p. (Contribuition, 36).

Garcia SLR, Leite HG, Yared JAG. Análise do perfil do tronco de morototó (Didymopamax morototonii) em função do espaçamento. In: $1^{\text {o }}$ Anais do Congresso Florestal Panamericano; $7^{\circ}$ Congresso Florestal Brasileiro. Curitiba: SBS/ SBEF; 1993. p.485-91.

Gonçalves JLM, Alvares CA, Behling M, Alves JM, Pizzi CT, Angeli A. Produtividade de plantações de eucalipto manejadas nos sistemas de alto fuste e talhadia, em função de fatores edafoclimáticos. Scientia Forestalis. 2014;42(103):411-9.

Horle DC, Mendonça AR, Carvalho SPC, Calegario N. Modelagem não linear do perfil longitudinal de fustes de Pinus oocarpa. Cerne. 2010;16(2):177-84.

Kohler SV, Koehler HS, Figueiredo Filho A, Arce JE, Machado SA. Evolution of tree stem taper in Pinus taeda stands. Ciência Rural. 2016;46(7):1185-91.

Kozak A, Munro DD, Smith JHG. Taper functions and their application in forest inventory. Forestry Chronicle. 1969;45(4):278-83.

Leite DR, Miguel EP, Santos GA, Encinas JMI, Rezende AV. Análise comparativa entre dois procedimentos para estimativa da variável volume em um povoamento de Eucalyptus urophylla, no município de Mineiros - Goiás. Enciclopédia Biosfera. 2011;7(13):1684-700.
Leite HG, Gama JRV, Cruz JP, Souza AL. Função de afilamento para Virola surinamensis (Roll.) Warb. Revista Árvore. 2006;30(1):99-106.

Menéndez-Miguélez M, Canga E, Alvarez-Alvarez P, Majada J. Stem taper function for sweet chestnut (Castanea sativa Mill.) coppice stands in northwest Spain. Annals of Forest Science. 2014;71:761-70.

Miguel EP, Cerdeira ALN, Azevedo GB, Azevedo GTOS, Humberto A, Pereira RS et al. Compatibility between wood volume estimation methods in a Eucalyptus stand. Australian Journal of Basic and Applied Sciences. 2015;9:371-6.

Môra R, Silva GF, Gonçalves FG, Soares CPB, Chichorro JF, Curto RA. Análise de diferentes formas de ajuste de funções de afilamento. Scientia Forestalis. 2014;42(102):237-49.

Nogueira SN, Leite HG, Reis GG, Moreira AM. Influência do espaçamento inicial sobre a forma do fuste de árvores de Pinus taeda L. Revista Árvore. 2008;32(5):855-60.

Ormerod DW. A simple bole model. Forestry Chronicle. 1973;49(3):136-8.

Özçelik R, Crecente-Campo F. Stem taper equations for estimating merchantable volume of lebanon cedar trees in the Taurus mountains, Southern Turkey. Forest Science. 2016;62(1):78-91.

Prodan M, Peters R, Cox F. Mensuração florestal. San José: IICA; 1997. 586p.

Queiroz D, Machado SA, Figueiredo Filho A, Arce JE, Koehler HS. Identidade de modelos em funções de afilamento para Mimosa scabrella Bentham em povoamentos nativos da região metropolitana de Curitiba/PR. Floresta. 2008;38(2):339-49.

Regazzi AJ. Teste para verificar a igualdade de parâmetros e a identidade de modelos de regressão não-linear. Revista Ceres. 2003;50(287):9-26.

Rodríguez-Toro A, Rubilar-Pons R, Muñoz-Sáez F, Cártes-Rodríguez E, Acuña-Carmona E, CancinoCancino J. Taper model by type of soil for Pinus radiata in the regions of Biobío and the

Revista Árvore. 2017;41(2):e410211 
Araucanía, Chile. Revista Chapingo Serie Ciencias Forestales y del Ambiente. 2016;22(2):203-20.

Silva F, Dalla Corte AP, Sanquetta CR. Equações de afilamento para descrever o volume total do fuste de Pinus caribaea var. hondurensis na região do Triângulo Mineiro. Scientia Forestalis. 2011;39(91):367-76.

Silva LMS, Rodriguez LCE, Caixeta Filho JV, Bauch SC. Fitting a taper function to minimize the sum of absolute deviations. Scientia Agricola. 2006;63(5):460-70.

Silveira P. Ajuste de modelos matemáticos para estimar biomassa aérea em Floresta Ombrófila Densa. Floresta. 2009;39(4):743-52.

Soares CPB, Martins FB, Leite Junior HU, Silva GF, Figueiredo LTM. Equações hipsométricas, volumétricas e de taper para onze espécies nativas. Revista Árvore. 2011;35(5):1039-51.
Souza RR, Nogueira GS, Murta Júnior LS, Pelli E, Oliveira MLR, Abrahão CP et al. Forma de fuste de árvores de Eucalyptus em plantios com diferentes densidades iniciais. Scientia Forestalis, 2016;44(109):33-40.

Statsoft, Inc. Statistica (data analysis software system), version 7.0. Cary: 2004.

Tang X, Pérez-Cruzado C, Fehrmann L, ÁlvarezGonzález JG, Lu Y, Kleinn C. Development of a compatible taper function and stand-level merchantable volume model for chinese fir plantations. PLoS ONE. 2016;11(1):1-15.

Téo SJ, Marcon A, Ehlers T, Bianchi JA, Peloso A, Nava PR, Costa RH. Modelos de afilamento para Pinus elliottii em diferentes idades, na região de Caçador, SC. Floresta. 2013;43(3):439- 52.

Vendruscolo DGS, Drescher R, Carvalho SPC, Souza HS, Silva RS, Chaves AGS. Forma do fuste de árvores de Tectona grandis em diferentes espaçamentos. Advances in Forestry Science. 2016;3(3)51-4. 